\title{
Role of Viruses in Periodontal Diseases: A Review
}

\author{
Neha Taneja, Praveen Kudva, Monika Goswamy, Geetha Bhat and Hema P. Kudva \\ Department of Periodontics and Oral Implantology, Jaipur Dental College, Jaipur, \\ (Rajasthan)-302028, India \\ *Corresponding author
}

\section{A B S T R A C T}

\begin{tabular}{|l|}
\hline Ke y w or d s \\
Periodontala, \\
Etiology, \\
Diseases. \\
\hline Article Info \\
\hline $\begin{array}{l}\text { Accepted: } \\
21 \text { May } 2017 \\
\text { Available Online: } \\
\text { 10 June } 2017\end{array}$ \\
\hline
\end{tabular}

\section{Introduction}

Periodontal disease is a polymicrobial infection involving a variety of microbes that trigger inflammation, loss of connective tissue attachment and alveolar bone around the teeth. The development of human periodontitis may depend upon cooperative interactions among herpes viruses, specific pathogenic bacteria and tissue destructive inflammatory mediators.

The subgingival presence of both EBV and HCMV was reported to be associated with the major periodontopathic bacteria and the severity of periodontal disease (Brogden et al., 2002; Cochran, 2008).

The hypothesis of a correlation between HCMV and EBV infection and the pathogenesis and progression of aggressive periodontitis has been proposed by various studies (Slots et al., 2003; Winkler et al., 1987; Winkler et al., 1989). The present review article is an attempt to elaborate the role of viruses in periodontal diseases.

\section{What are viruses?}

An infective agent that typically consists of a nucleic acid molecule in a protein coat, is too small to be seen by light microscopy, and is able to multiply only within the living cells of a host.

\section{Classification of viruses}

At first, Bawden (1941) gave the hypothesis that viral nomenclature and classification should be based on the properties of viruses and not upon host responses. From the early 1950s, viruses began to be classified into 
groups based on their physicochemical and structural features.

As per International Committee on Taxonomy of Viruses (2005) viruses are classified into two main divisions depending on the type of nucleic acid they possess:

Riboviruses are those containing RNA

Deoxy-riboviruses are those containing DNA.

\section{Periodontal diseases caused by viruses}

\section{HIV}

Periodontal pathology associated with the HIV-infected patient can be classified into three distinct categories:

Linear gingival erythema;

Necrotizing ulcerative periodontal diseases, including necrotizing ulcerative gingivitis, necrotizing ulcerative periodontitis, and necrotizing ulcerative stomatitis;

Enhanced progression of chronic adult periodontitis.

Initially, reports describing necrotic lesions of the periodontium and intense marginal gingival erythema in HIV-infected patients were published in the mid-1980s (Contreras et al., 1999; 2000; Gornitsky et al., 1987).

The current American Academy of Periodontology terminology for HIV-G lesions is linear gingival erythema and for HIV-P lesions is necrotizing ulcerative periodontitis (Graves, 2008; Hofbauer et al., 2004).

\section{Linear gingival erythema}

Linear gingival erythema is defined as a gingival manifestation of immunosuppressed patients, which is characterized by a distinct linear erythema limited to the free gingival margin.

The lack of response of linear gingival erythema lesions to conventional periodontal therapy, including plaque control, and root planing and scaling, is a key diagnostic feature of linear gingivalerythema because it is difficult to distinguish linear gingival erythema clinically from severe gingivitis in patients with poor plaque control. Another key diagnostic feature of linear gingival erythema is its association with Candida infection. It has been reported that the extent of linear gingival erythema may be influenced by the use of tobacco (Contreras et al., 2000).

Grbic et al., found that oral candidiasis was closely associated with the presence of linear gingival erythema.

Because of the evidence that Candida infection is the primary etiology of linear gingival erythema, the American Academy of Periodontology has classified linear gingival erythema as a gingival disease of fungal origin. The presence of Candida within the gingival tissues can explain the inability of conventional periodontal therapy to control linear gingival erythema. It can progress to necrotizing diseases in some cases.

\section{Necrotizing diseases of the periodontium in HIV infected patients}

Necrotizing ulcerative gingivitis and necrotizing ulcerative periodontitis are two related periodontal lesions that have been found in both HIV-infected and non-infected patients.

The American Academy of Periodontology has classified them together as necrotizing periodontal diseases Necrotizing ulcerative gingivitis typically presents as ulceration of the interdental papilla with gingival bleeding 
and severe pain (Contreras et al., 1999). The lesion is commonly described as having a punched out appearance of the interproximal papilla, and the affected area typically appears to be covered with a fibrinous pseudo membrane. For a diagnosis of necrotizing ulcerative gingivitis to be made, the lesion must exhibit all three signs. Other signs and symptoms of necrotizing ulcerative gingivitis or necrotizing ulcerative periodontitis may include oral malodor, lymphadenopathy, fever, and malaise; however, these findings are inconsistent.

Cobb et al., (2004) using electron microscopy, compared the microbiology of necrotizing ulcerative periodontitis in HIVinfected subjects with necrotizing ulcerative gingivitis lesions of HIV-negative subjects and found that spirochetes, zones of aggregated polymorph nuclear leukocytes, and necrotic cells typically found in necrotizing ulcerative gingivitis lesions were also found in necrotizing ulcerative periodontitis lesions, suggesting that the two lesions had a similar microbiology and pathogenesis.

\section{Herpes virus}

\section{Classification}

Human herpes viruses are classified based on details on tissue tropism, pathogenicity and behavior under conditions of culture in the laboratory.

$\alpha$-Herpes viruses: Neurotropic, have rapid replication cycle and displays broad host and cell range e.g. HSV-1\&2, Varicella zoster.

$\beta$ - and $\gamma$ - Herpes viruses: differ in genomic size and structure, but replicate relatively slow and in the restricted range of cells mainly of lymphatic and nodular origin e.g. for $\beta$ - HCMV, HHV-6, HHV-7 and for $\gamma-$ EBV, HHV-8.

\section{Epstein-Barr virus}

Epstein-Barr virus affects over $90 \%$ of humans (Cohen, 1997), and is usually transmitted by oral secretions or blood. The virus replicates in epithelial cells or B cells of the oropharynx. Nearly all seropositive persons actively shed virus in the saliva (Yao et al., 1985). Resting memory B cells are the main site of persistence of EBV in the body (Cohen, 1997).

Pathogenesis (Winkler et al., 1988; Yapar et al., 2003)

The virus enters the pharyngeal epithelial cells, multiplies locally, invades the bloodstream and infects B lymphocytes in which two types of changes are produced:

The virus becomes latent inside the lymphocytes

Progeny virions (Lamster et al., 2007)

Intermittent reactivation of the latent $\mathrm{EB}$ virus leads to clonal proliferation of infected $\mathrm{B}$ cells.

In immuno competent subjects, this is kept in check by activated $\mathrm{T}$ cells.

In the immuno deficient, B cell clones may replicate unchecked, resulting in lymphomas (Yapar et al., 2003).

Infectious mononucleosis is a symptomatic disease resulting from exposure to EpsteinBarr virus (EBV, HHV-4). The infection usually occurs by intimate contact. Intrafamilial spread is common Adults usually contract the virus through direct salivary transfer, such as shared straws or kissing, hence the nickname "kissing disease." Most EBV infect ions in children are asymptomatic, in children younger than 4 years of age with symptoms. 
Most have fever, lymphadenopathy, pharyngitis, hepatosplenomegaly, and rhinitis or cough. Oral lesions other than lymphoid enlargement include petechiae on the hard or soft palate, necrotizing ulcerative gingivitis (NUG).

\section{Cytomegalo virus}

Herpes viruses are found to be more frequently present in periodontal lesions and acute necrotizing ulcerative gingivitis lesions than in gingivitis or periodontally healthy sites. Most of the time, two herpes viruses are implicated in these lesions: Epstein-Barr virus
(EBV) that infects periodontal B-lymphocytes and cytomegalovirus (CMV) that infects periodontal monocytes/macrophages and $\mathrm{T}$ lymphocytes. Also, CMV infects salivary glands, epithelial and endothelial cells, and fibroblasts. The seroprevalence of CMV infection in the world varies widely up to $95 \%$ of population depending on the geographic area (developed/developing countries) (Neville). Very often, the infection starts early in the childhood, actually, early in gestation because placenta is pivotal in CMV transmission to the foetus (Offenbacher et al., 2008) (Table 1).

Fig.1 Sites of action of various anti-viral drugs

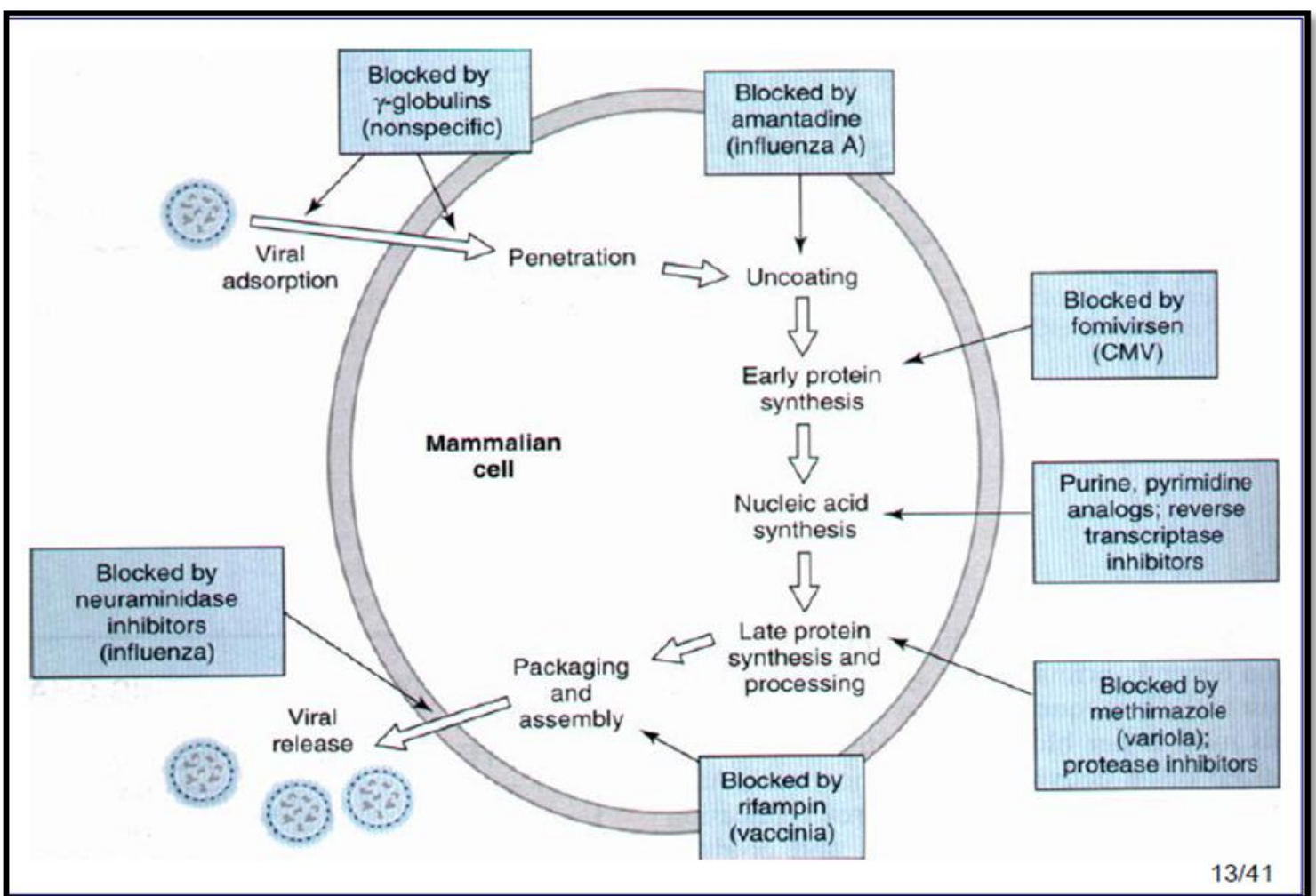


Table.1 Oral viral diseases

\begin{tabular}{|c|c|c|c|}
\hline Disease & Virus & Systemic symptoms & Oral symptoms \\
\hline Measles & Measles & $\begin{array}{l}\text { cough, conjunctivitis, } \\
\text { fever, photophobia, } \\
\text { rhinitis }\end{array}$ & $\begin{array}{l}\text { Koplik spot } \\
\text { (Irregular red-brick maculopapular skin } \\
\text { rash). } \\
\text { Candidiasis, necrotizing ulcerative } \\
\text { gingivitis and necrotizing stomatitis may } \\
\text { be present. }\end{array}$ \\
\hline Mumps & Mumps & $\begin{array}{l}\text { Orchitis, aseptic } \\
\text { meningitis, pancreatis and } \\
\text { oophoritis. }\end{array}$ & $\begin{array}{l}\text { Redness and enlargement of Wharton's } \\
\text { and Stenson's salivary gland duct } \\
\text { openings. involvement of the sublingual } \\
\text { gland may produce bilateral } \\
\text { enlargements of the floor of the mouth }\end{array}$ \\
\hline $\begin{array}{l}\text { Hand, foot } \\
\text { and mouth } \\
\text { disease }\end{array}$ & $\begin{array}{l}\text { Coxsackie } \\
\text { viruses }\end{array}$ & Ulcers on hands and feet & $\begin{array}{l}\text { Square blisters on buccal mucosa, soft } \\
\text { palate }\end{array}$ \\
\hline Herpangina & $\begin{array}{l}\text { Coxsackie } \\
\text { virus }\end{array}$ & $\begin{array}{l}\text { Headache, high fever, } \\
\text { myalgia }\end{array}$ & Clustered petechiae \\
\hline $\begin{array}{l}\text { Squamous } \\
\text { cell } \\
\text { papilloma }\end{array}$ & HPV & & Cauliflower like growth of oral mucosa \\
\hline $\begin{array}{l}\text { Verruca } \\
\text { vulgaris }\end{array}$ & HPV & & $\begin{array}{l}\text { Exophytic growth on gingiva, labial } \\
\text { mucosa,c ommissure, hard palate or } \\
\text { tongue }\end{array}$ \\
\hline $\begin{array}{l}\text { Focal } \\
\text { epithelial } \\
\text { hyperplasia }\end{array}$ & HPV & & Multiple papular lesions on oral mucosa \\
\hline $\begin{array}{l}\text { Oral lichen } \\
\text { planus }\end{array}$ & HPV & Erosive lesion on skin & Erosive lesion on oral mucosa \\
\hline $\begin{array}{l}\text { WHIM's } \\
\text { syndrome }\end{array}$ & HPV & $\begin{array}{l}\text { Hypogammaglobulinemia, } \\
\text { infection, myelokathexis }\end{array}$ & Warts \\
\hline $\begin{array}{l}\text { Herpetic } \\
\text { gingivostom } \\
\text { atitis }\end{array}$ & HSV & $\begin{array}{l}\text { anterior cervical } \\
\text { lymphadenopathy, chills, } \\
\text { fever (103' to IDS ' Fl. } \\
\text { nausea. anorexia, } \\
\text { irritability. and sore mouth } \\
\text { lesions }\end{array}$ & Painful vesicular lesion on gingiva \\
\hline $\begin{array}{l}\text { Infectious } \\
\text { mono } \\
\text { nucleosis }\end{array}$ & & & $\begin{array}{l}\text { Lymphoid enlargement, petechiae on } \\
\text { the hard or soft palate, Necrotizing } \\
\text { ulcerative gingivitis (NUG) }\end{array}$ \\
\hline $\begin{array}{l}\text { Varicella } \\
\text { zoster virus }\end{array}$ & & $\begin{array}{l}\text { Fever, malaise. } \\
\text { Advanced stages } \\
\text { neurological } \\
\text { complications might arise }\end{array}$ & Vesicles and ulcer in oral cavity \\
\hline
\end{tabular}


Table. 2 Various antiviral drugs and their doses

\begin{tabular}{|l|l|l|}
\hline Medication & Trade Name & Dose \\
\hline Interferon alfa-2b & Intron A & 5 million IU sq qd or 10 million IU sq 3x/week \\
\hline Peginterferon alfa-2a & Pegasys & $180 \mathrm{mcg}$ subcutaneously once weekly \\
\hline Lamivudine (3TC) & $\begin{array}{l}\text { Epivir-HBV }(100 \mathrm{mg}) \\
\text { Epivir }\end{array}$ & $\begin{array}{l}100 \mathrm{mg} \text { PO qd } \\
300 \mathrm{mg} \text { PO qd (or } 150 \mathrm{mg} \text { PO bid) for HIV-coinfected }\end{array}$ \\
\hline Adefovir (ADV) & Hepsera & $10 \mathrm{mg} \mathrm{PO} \mathrm{qd}$ \\
\hline Entecavir (ETV) & Baraclude & $\begin{array}{l}0.5 \mathrm{mg} \text { PO qd for treatment-naïve patients } \\
1 \mathrm{mg} \text { PO qd for patients with lamivudine resistance }\end{array}$ \\
\hline $\begin{array}{l}\text { Telbivudine (LdT) } \\
\text { Tyzeka }\end{array}$ & $600 \mathrm{mg}$ PO qd \\
\hline $\begin{array}{l}\text { Tenofovir (TDF) } \\
\text { Viread }\end{array}$ & $300 \mathrm{mg}$ PO qd \\
\hline $\begin{array}{l}\text { Abbreviations } \\
\text { IU = international units } \\
\text { sq = subcutaneously } \\
\text { qd = once daily } \\
\text { bid = twice daily }\end{array}$ &
\end{tabular}

\section{Viruses in pregenancy gingivitis}

Gu“lden Eresx, Elif Altıok, Aykut O"zkul, and Cengiz Han Acxikel studied that pregnancy increases the risk of the presence of sub gingival EBV in pregnant women by 3.647 times more than that of non-pregnant women.

\section{Bacterial-viral interaction}

While the role of bacterial plaque in general seems to be evident, the following observations indicate that other functions may contribute to the development of periodontal diseases.

Although all subjects with poor oral hygiene develop gingivitis, not every gingivitis lesion invariably leads to attachment loss.

There is a high prevalence of potential bacterial pathogens in certain populations despite a large variation in general levels of oral hygiene.

Global epidemiological data infers that the progression of destructive periodontitis is subject related and comparatively few individuals in the population show advanced periodontal breakdown.

The activities of periodontal sites have been demonstrated to be episodic with periods of quiescence and activation.

These uncertainties have galvanized efforts to find additional etiologic factors for periodontitis. This led to numerous researches probing to explore the possible causative factors for periodontal destruction. Important advances in understanding the infectious agents of periodontal disease have occurred in the past three decades making major inroads into the microbiology, immunology and cause related treatment of periodontal diseases. In the past decade various viruses have emerged as putative pathogens in destructive periodontal disease particularly HIV and Herpes virus.

\section{Treatment}

A prompt diagnosis of viral diseases is based upon the quantitative and qualitative 
assessment of viral loads. Treatment of viral diseases is based upon administration of topical and systemic antivirals drugs in conjunction with scaling and root planning, $0.12 \%$ chlorhexidine mouthwash (Table 2 and Fig. 1).

A solid understanding of the etiology of periodontitis is critical for developing clinically relevant classification systems and therapies that can ensure long lasting disease control. Research during the past 15 years has implied that herpesviruses are involved in the etiopathogeny of destructive periodontal disease (Saygun et al., 2004; Slots et al., 2004). Hopefully, increased knowledge of the immunovirology of cytomegalovirus and other herpes viruses in periodontitis may lead to a greater understanding of periodontal host responses and to more effective preventive and therapeutic interventions, including future vaccination against periodontopathic Herpes viruses.

\section{References}

Brogden, K.A., Guthmiller, J.M., editors. 2002. Polymicrobial Diseases. Washington, DC: ASM Press, Pp. 317 331.

Cochran, D.L. 2008. Inflammation and bone loss in periodontal disease. $J$. Periodontol., 79: 1569-76.

Contreras, A., Slots, J. 2000. Herpesviruses in human periodontal disease. $J$. Periodontal. Res., 35: 3-16.

Contreras, A., Zadeh, H.H., Nowzari, H., Slots, J. 1999. Herpesvirus infection of inflammatory cells in human periodontitis. Oral Microbiol. Immunol., 14: 206-212.

Gornitsky, M., Pekovic,

D. 1987. Involvement of human immunodeficiency virus (HIV) in gingiva of patients with AIDS. $A d v$. Exp. Med. Biol., 216A: 553-562.
Graves, D. 2008. Cytokines that promote periodontal tissue destruction. $J$. Periodontol., 79: 1585-91.

Hofbauer, L.C., Schoppet, M. 2004. Clinical implications of the osteoprotegerin/RANKL/RANK system for bone and vascular disorders. JAMA, 292: 490-5.

Holmstrup, P. 1999. Non plaque-induced gingival lesions. Ann. Periodontol., 4: 20-31.

Hosokawa, Y., Hosokawa, I., Ozaki, K., Nakae, H., Matsuo, T. 2008. Cytokines differentially regulate cxcl10 production by interferon- $\gamma$-stimulated or tumor necrosis factor- $\alpha$-stimulated human gingival fibroblasts. J. Periodontal. Res., 44: 225-31.

Kinney, J.S., Ramscier, C.A., Giannobile, W.V. 2007. Oral fluid-based biomarkers of alveolar bone loss in periodontitis. Ann. N.Y. Acad. Sci., 1098: 230-51.

Lamster, I.B., Ahlo, J.K. 2007. Analysis of gingival crevicular fluid as applied to the diagnosis of oral and systemic diseases. Ann. N.Y. Acad. Sci., 1098: 216-29.

Neville, B.W. Textbook of oral and maxillofacial pathology, 2nd edition.

Offenbacher, S., Barros, S.P., Beck, J.D. 2008. Rethinking periodontal inflammation. J. Periodontol., 79: 157784.

Page, R.C., Schroeder, H.E. 1981. Current status of the host response in chronic marginal periodontitis. J. Periodontol., 52: 477-91.

Saygun, I., Kubar, A., O“ zdemir, A., Yapar, M., Slots, J. 2004. Herpesviral- bacterial interrelationships in aggressive periodontitis. J. Periodontal. Res., 39: 207-212.

Slots, J., Nowzari, H., Sabeti, M. 2004. Cytomegalovirus infection in symptomatic periapicalpathosis. Int. Endod. J., 37: 519-524. 
Slots, J., Sabeti, M., Simon, J.H. 2003. Herpesviruses in periapicalpathosis: an etiopathogenic relationship? Oral Surg. Oral Med. Oral Pathol. Oral Radiol. Endod., 96: 327-331.

Winkler, J.R., Grassi, M., Murray, P.A. 1988. Clinical description and etiology of HIV associated periodontal disease. PSG Publishing Company: Littleton.

Winkler, J.R., Murray, P.A. 1987. Periodontal disease. A potential intraoral expression of AIDS may be rapidly progressive periodontitis. CDA J., 15: 20-24.

Winkler, J.R., Murray, P.A., Grassi, M., Hammerle, C. 1989. Diagnosis and management of HIV-associated periodontal lesions. J. Am. Dent. Assoc., 25S-34S.

Yapar, M., Saygun, I., Ozdemir, A., Kubar, A., Sahin, S. 2003. Prevalence of human herpesviruses in patients with aggressive periodontitis. J. Periodontol., 74: 1634-1640.

\section{How to cite this article:}

Neha Taneja, Praveen Kudva, Monika Goswamy, Geetha Bhat and Hema P. Kudva. 2017. Role of Viruses in Periodontal Diseases: A review. Int.J.Curr.Microbiol.App.Sci. 6(6): 1481-1488. doi: https://doi.org/10.20546/ijcmas.2017.606.174 